\title{
NAS CAUSAS DE UM SINTOMA SOCIAL O BIBLIOTECÁRIO ATUA: A MEDIAÇÃO E USO DA INFORMAÇÃO COMO FONTE DE INTERPOSIÇÃO SOBRE O VÍRUS HIV
}

\author{
ON THE CAUSES OF A SOCIAL SYMPTOM THE LIBRARIAN ACTS: \\ MEDIATION AND USE OF INFORMATION AS A SOURCE OF \\ BRINGING ABOUT THE VIRUS HIV
}

\section{Alessandra Nunes de Oliveira ${ }^{1}$ Jetur Lima de Castro ${ }^{2}$}

\begin{abstract}
RESUMO
Trata da importância que o profissional bibliotecário possui como mediador da informação, frente à realidade dos casos sociais, no que se refere aos conceitos sobre o HIV/AIDS. E a sua seriedade em grupo, para levar assistência através das informações, como alicerces contra as crendices e equívocos a respeito do vírus HIV. A temática é relevante para todas as áreas, pois, apresenta as discussões sobre os preconceitos e mitos no início dos anos 80. Sobretudo tem seus objetivos pautados em abordar a formação social dos próprios profissionais da informação, sobretudo a contribuição do bibliotecário diante de ações sociais concernentes ao contexto e a disseminação do vírus HIV. A metodologia utilizada foi exploratória sobre uma revisão bibliográfica dos, Almeida Júnior (1997) e Marques (2002), entre outros. Em resumo a pesquisa utilizou duas fontes de informações como as bases a MEDLINE, e BVS em que buscou artigos publicados na década de 80, dentre outros encontrados artigos referentes às drogas inibidoras do Vírus HIV entre elas a chamada Zidovudine (AZT). Os resultados mostram a falta de informação, o preconceito no qual ainda perduram no contexto social. Porquanto os profissionais da informação, neste ponto ressalto o bibliotecário, que é imprescindível neste contexto, onde contribui com os profissionais da saúde, para tirar as incertezas, auxiliando nas informações convalidadas para os próprios portadores do vírus e a sociedade.
\end{abstract}

PALAVRAS-CHAVE: Mediação da informação; Ação social; Profissional da informação; Bibliotecário; HIV.

\begin{abstract}
It is of importance that the professional librarian has as a mediator of information vis-à-vis the reality of social cases, with regard to concepts about the HIVAIDS. And their seriousness in-group, to bring assistance through the information, as foundations against the superstitions and misconceptions regarding HIV/AIDS. The theme is relevant to all areas therefore presents the discussions about prejudices and myths in the early 80 . Above all have their goals based on addressing the social formation of own information professionals, especially the contribution of the librarian on social action for the context and the spread of the HIV virus. The methodology was a bibliographical revision about the exploratory, Almeida Júnior (1997) and Marques (2002), among others. In summary, the research used two sources of information such as the bases MEDLINE, and VHL in that sought articles published in the Decade of 80, among others found articles about the drugs that inhibit HIV among them called Zidovudine (AZT). The results show a lack of information, in which prejudice still linger in the social context. Because information workers at this point rebound the librarian, which is essential in this context, where it contributes to health professionals, to take the uncertainties, assisting on the information convalidadas to the virus carriers themselves and society.
\end{abstract}

KEYWORDS: Mediation of information; Social action; Information worker; Librarian; HIV.

\footnotetext{
Estudante de Biblioteconomia da Universidade Federal do Pará - Campus Belém. E-mail: alessandranunesoliveira@gmail.com

2 Estudante de Biblioteconomia da Universidade Federal do Pará - Campus Belém. Estagiário em Gerenciamento, Digitalização de acervos e documentos Antigos no Museu Paraense Emílio Goeldi (MPEG). Email: jetur.er@gmail.com

Recebido em: 04/11/2014 - Aceito em: 13/05/2015
} 


\section{INTRODUÇÃO}

O presente artigo aborda a importância que o profissional bibliotecário possui como disseminador da informação diante da realidade dos casos sociais, no que se refere aos conceitos sobre o $\mathrm{HIV}^{3}$ e a $\operatorname{AIDS}^{4}$. Na disposição de que os profissionais da informação podem levar assistência, através das informações como alicerces contra os preconceitos e equívocos a respeito do vírus no meio social. Na utilização de sua ferramenta de trabalho e competências no auxílio das questões sociais como disseminador de informações para aqueles que carecem de informações e como apoio.

Sabendo-se que o bibliotecário tem acesso as diferentes fontes de informações, para disseminar de maneira correta àqueles que necessitam. Este profissional tem sua contribuição para tirar as incertezas, auxiliando nas informações convalidadas para os próprios portadores do vírus HIV e a sociedade. Visto que, a informação enquanto forma de validade, torna-se uma ferramenta primordial contra a ignorância, podendo vir até mesmo mudar o pensamento social a respeito de determinados contextos. "A informação é qualificada como um instrumento modificador da consciência do indivíduo e da sociedade como um todo" (BARRETO, 2005, p.2).

Porquanto os profissionais da informação, neste ponto ressalta-se o bibliotecário, que é indispensável neste contexto, onde contribui com os profissionais da saúde, para tirar as incertezas, sobre o vírus HIV e as formas de contágios, no qual ainda persiste na mente da sociedade de forma, auxiliando nas fontes de informações para próprios portadores do vírus e a sociedade.

Visto que muitas das vezes o vírus HIV é confundido e até mesmo nivelado com a AIDS. O que é um equívoco por falta de informação. Pois o "HIV não é a mesma coisa que ter a AIDS. Há muitos soropositivos que vivem anos sem apresentar sintomas e sem desenvolver a doença" (DEPARTAMENTO..., online). Logo, a AIDS "resulta de estágios avançados de infecção pelo HIV e é caracterizada por infecções oportunistas" (BRASIL, 2014).

A responsabilidade social do bibliotecário frente ao assunto abordado é importante, pois, em sua maioria recupera, disseminar e mediar essas informações, agregam o conhecimento, considerado em seu juramento profissional em que se preza na liberdade de investigação científica e na dignidade do ser humano.

Visto que o bibliotecário não é apenas aquele que está inserido nas suas unidades de informações e processamentos, ele também pode ser considerado, como o profissional que atua em conjunto nas causas sociais levando ao indivíduo a clareza e o refletir sobre determinados assuntos. Pois segundo Campello (2003, p.30) o bibliotecário é profissional que

\footnotetext{
3 Sigla de expressão inglesa: Human Immunodeficiencie Virus. No qual corresponde a: vírus da imunodeficiência humana

${ }^{4}$ Sigla de expressão inglesa: Acquired Immunodeficience Sydrome. No qual corresponde a: síndrome de imunodeficiência adquirida. A sigla também conhecida como: SIDA.
} 
está "envolvido no desenvolvimento de habilidades de pensar criticamente, ler, ouvir e ver, enfim ensinando o aprender a aprender".

Sendo que a raiz dos preconceitos e medos ainda existentes, é decorrente das inúmeras informações falsas que ainda envolvem o vírus HIV e a falta de leituras e o pensar criticamente da sociedade. Decorrido das inúmeras informações falsas que ainda envolvem o assunto, o bibliotecário entra em ação na sua missão em "facilitar aos indivíduos o acesso à informação e possibilitar, desta forma, o desejo de aprender, de discutir (...) desta forma, nossa missão como agentes de transformação social é plenamente realizada" (CUNHA, 2003, p.46).

A temática é relevante para todas as áreas, pois, apresenta as discussões sobre os preconceitos e mitos no início dos anos 80. Sobretudo tem seus objetivos pautados em abordar a formação social dos próprios profissionais da informação, sobretudo a contribuição do bibliotecário de recuperar, disseminar e mediar essas informações, agregando o conhecimento diante de ações sociais referentes ao contexto e a disseminação do vírus HIV.

A metodologia utilizada foi a exploratória, assim Gil (2008) afirma que a pesquisa exploratória proporciona maior familiaridade com o problema (explicitá-lo). Pode envolver levantamento bibliográfico, entrevistas com pessoas experientes no problema pesquisado. A pesquisa exploratória apoia-se em determinados princípios bastante difundidos: 1) a aprendizagem melhor se realiza quando parte do conhecido; 2) deve-se buscar sempre ampliar o conhecimento e 3) esperar respostas racionais pressupõe formulação de perguntas também racionais (PIOVESAN, 1968).

Para o desenvolvimento da pesquisa foram utilizadas duas bases de dados, a exemplo a MEDLINE, no qual a pesquisa buscou saber, através dos artigos publicados na década de 80, como era descrita pela medicina o HIV na determinada época; e a BVS (Biblioteca Virtual em Saúde) onde foram encontrados artigos que refere as drogas inibidoras do Vírus HIV entre elas a chamada Zidovudine (sigla AZT) no qual então se encontra, publicado pelo Ministério da Saúde do Brasil.

O Portal ${ }^{5}$ sobre aids, doenças sexualmente transmissíveis e hepatites virais, ligado à Secretaria de Vigilância em Saúde do Ministério da Saúde, também foram consultados para maior entendimento e história do vírus no Brasil. Para a sistematização dessa pesquisa foram utilizadas também pesquisas bibliográficas de autores da área de Ciência da informação como Almeida Junior (1997), que aborda o bibliotecário como importante agente social na informação sobre a AIDS. Assim como Cunha (2003), no qual retrata o papel social do bibliotecário e Barreto (2005) no qual defende a informação como processo modificado da sociedade. E autores que abordam o vírus HIV em seus estudos como Grangeiro (2009) e Marques (2002).

Os resultados mostram a falta de informação, o preconceito no qual ainda perduram no contexto social. Porquanto os profissionais da informação, neste ponto ressalto o

\footnotetext{
${ }^{5}$ http://www.aids.gov.br
} 
bibliotecário, que é imprescindível neste contexto, onde contribui com os profissionais da saúde, para tirar as incertezas, auxiliando nas informações convalidadas para os próprios portadores do vírus e a sociedade.

A presente pesquisa conclui analisando o sensacionalismo midiático sobre o vírus HIV e a AIDS, que é confundido e até mesmo comparado com a AIDS. O que é um equívoco por carência de informação como já foi mencionado suas diferenças, a exemplo o cantor e compositor Cazuza, o primeiro artista brasileiro a confessar publicamente ser portador do vírus HIV. Abordando sua luta em sociedade como exemplo de portador que recebeu preconceito pelas falsas informações que a mídia repassava nos primeiros anos que o vírus se tornou conhecido no Brasil.

\section{HISTÓRICO DO HIV/AIDS NO BRASIL}

A medicina estava confiante com a chegada das tecnologias para o aprimoramento de suas novas pesquisas achando que estavam no controle das epidemias. Quando o choque de um vírus veio à tona encontrando médicos e cientistas surpresos deixando dúvidas e mistérios sobre sua origem, tratamento e forma de cura. Surgi o vírus no qual se tornou conhecido como o mal do século.

A AIDS, epidemia que surgiu numa época em que as autoridades sanitárias mundiais acreditavam que as doenças infecciosas estavam controladas pela tecnologia e saber médicos modernos, suscitou comportamentos e respostas coletivos, nos quais estão inseridas as estratégias políticas oficiais em seus diversos contextos (MARQUES, 2002, p. 43).

A sigla HIV procedente do nome científico inglês Human Immunodeficiency Virus (vírus da imunodeficiência humana) é o agente causador da AIDS Acquired Immunological Deficience Syndrome (síndrome de imunodeficiência adquirida). Os primeiros históricos no Brasil do vírus da imunodeficiência humana conhecida como HIV, causador da AIDS, teve seu reconhecimento em 1982, no estado de São Paulo (MARQUES, 2002). "Na primeira metade da década de 80, a identificação de novos casos manteve-se restrita aos estados de São Paulo e Rio de Janeiro, nos grandes centros urbanos" (SADALA; MARQUES, 2006, p.2369).

No início da pandemia, os casos se restringiam a um determinado grupo, sendo por isso adotado temporariamente o termo Doença dos $5 \mathrm{H}$ - Homossexuais, Hemofílicos, Haitianos, Heroinômanos (usuários de heroína injetável), Hookers (profissionais do sexo em inglês), ou seja, foram conhecidos os possíveis fatores de transmissão (SOUSA, et al., 2012, p. 63).

Pela falta de informações e os estudos ainda recentes sobre o vírus HIV, desencadeou preconceitos da sociedade sobre diferentes grupos. Os homossexuais foram alvos das primeiras discriminações, atribuindo a AIDS como consequência de costumes promíscuos.

A AIDS ganhou a mídia no Brasil no dia 3 de Junho de 1983 quando o jornal Folha de S. São Paulo publicava matéria com o título congresso debate doença comum entre homossexuais. Alguns dias depois, em 12 de junho, foi à vez do Jornal do 
Brasil: Brasil registra dois casos de câncer gay; enquanto o hoje extinto jornal Noticias populares estampava na edição 116 de Junho a manchete Aids: doença de gays (BRASIL, $2005^{\mathrm{b}}$, p. 18).

O preconceito não se subsidiou apenas nos grupos discriminados, mas também nas relações sociais com os portadores chegando a pensar em não poder apertar a mão do portador pela crença que poderia ocorrer o contágio. Assim como “o termo 'aidético' passou a ser amplamente utilizado, simbolizando a forma pela qual a sociedade reconhecia a doença e o doente" (GRANGEIRO, et al., 2009, p. 90). Os equívocos eram tomados em proporções amplas, a partir do diagnóstico detectado era sinônimo de passaporte para a morte. Já que os portadores perdiam a luta contra o vírus em pouco tempo devido às infecções oportunistas. Ocasionando muitas dúvidas e aflições aos portadores, no qual muitas das vezes se isolavam da vida em sociedade para evitar preconceitos.

Entretanto o primeiro tratamento iniciou com a droga zidovudina mais conhecido como o AZT em 1987 (BRASIL, 2005 ${ }^{\text {b }}$ ) ocasionando as primeiras chances de tratamentos para tornar o vírus controlado. Sendo assim "O Brasil foi um dos primeiros países em desenvolvimento a garantir o acesso universal e gratuito aos medicamentos antirretrovirais no Sistema Único de Saúde (SUS), a partir de 1996" (DOURADO, et al., 2006, p. 2).

O Brasil, atualmente, apresenta uma das políticas de enfrentamento à AIDS mais moderna do mundo, destacando-se a forte organização social para a formulação desta, o acesso às drogas terapêuticas, a mobilização da comunidade internacional e o movimento de reforma sanitária (SOUSA, et al.,2012, p.63).

Diante dos avanços sobre o vírus HIV e suas formas de tratamento, muito ainda precisa ser feito, no que diz respeito não apenas no desempenho dos medicamentos antirretrovirais, mas também na informação sobre o vírus. Pois o preconceito ainda se subsidia na sociedade.

O conhecimento do HIV/AIDS também ocorreu através de alguns artistas que eram portadores e vieram à tona na mídia. A década de 80 ocasionada por diversas transformações políticas, artísticas, musicais e econômicas, traz consigo, o estado alarmante na saúde. Dando destaque à frase "a década perdida" em que se tornou consagrada.

\section{SENSACIONALISMO $x$ SOCIEDADE}

Na sociedade atual o governo tem investido em coquetéis, anúncios para prevenções e exames. Pessoas que possuem o vírus conseguem viver melhor em comparação dos portadores do início da década de 80 . As formas de tratamentos evoluíram, mas a forma que está sendo repassada a notícia sobre o vírus, tem muito a ser feito em sua caminhada para chegar mais longe na sociedade.

O preconceito ainda vem subsistindo na mente da sociedade e até dos indivíduos que possuem o medo de efetuar o teste para saber seu resultado. A falta de informação de como 
encarar a realidade, é o que ocasiona o medo para que o Indivíduo não faça o exame, seja por medo de enfrentar a sociedade diante do preconceito ou por não saber ao certo como será sua vida após o diagnóstico.

Conforme Meneghin (1996, p.400) "em meio a este cenário de confusão e divergências, a ignorância e a desinformação sobre a AIDS foram um legado prejudicial à comunidade [...]". O vírus HIV/AIDS por certo tempo foi visto como a doença maligna, devido à mídia focalizar constantemente sobre o assunto ocasionando aos portadores perderem a luta contra o vírus e se privando da sociedade. As informações falaciosas que eram disseminadas nos meios de comunicação trouxeram como consequência, o preconceito e o medo que a sociedade possuía a respeito. Em 1981, as notícias sobre AIDS eram alarmantes e sensacionalistas causavam pânico, medo e discriminação entre a população (BRASIL, $1998^{\mathrm{c}}$ ).

A partir de 1983, a AIDS se transformou em notícia quase cotidiana na grande imprensa e também na imprensa sensacionalista. Algumas dessas matérias semearam pânico na população e cristalizaram imagens moralistas e discriminatórias que pouco correspondia ao perfil da epidemia que se iniciava (GRANGEIRO, et al., 2009, p.90).

Em contribuição às informações sensacionalistas à revista VEJA de 1989, edição 1.077, estampou em sua capa a reportagem "Cazuza uma vítima da AIDS agoniza em praça pública" na qual, trazia a foto do cantor com pouco cabelo, visivelmente abatido. Para quem conhecia o artista, a foto deixava a entender que Cazuza já não era o mesmo fisicamente. Em uma década que ainda desconhecia o vírus HIV, a revista VEJA já possuía grande circulação, impressionou a sociedade com sua imagem e texto sensacionalista na capa. Tendo incomodado o próprio cantor vítima da apelação feita. No qual em resposta pela atitude, Cazuza redigiu uma carta criticando a matéria e a revista.

Tristeza porr essa revista ceder à tentação de descer ao sensacionalismo, para me sentenciar à morte em troca da venda de alguns exemplares a mais. Se os seus repórteres e editores tinham de antemão determinado que estou em agonia, deviam, quando nada, ter tido a lealdade e fraqueza de o anunciar para mim mesmo, quando foram recebidos cordialmente em minha casa (ARAÚJO, 2000, p. 111).

Para uma sociedade que não conhecia ao certo do que se tratava o vírus, uma matéria em que coloca como referencial um artista popular com aids e o estado em que se encontrava por possuir o vírus, causou um choque tanto para os portadores, quanto para a sociedade, por se tratar de uma revista de grande circulação trazendo à tona um ícone nacional, acentuando ainda mais o preconceito. Segundo Grangeiro, et al., (2009, p. 90) "essas notícias foram os primeiros contatos que a sociedade Brasileira teve com a aids e contribuíram para reforçar a imagem do doente (...) do preconceito associado a grupos sociais e do sofrimento do paciente".

Através do sensacionalismo midiático não só visto pela revista VEJA, mas por outros meios de comunicação que encandeavam ainda mais as incógnitas do vírus. Pereira e Nichiata (2011, p.3) afirmam que “ (...) as publicações na imprensa sobre a AIDS tinham 
como marcas o preconceito e o moralismo". A sociedade passou a conviver com o estado de pânico acreditando em equívocos no qual acreditavam que não poderiam emprestar roupa, abraçar e compartilhar o mesmo prato e talheres na concepção que tudo seria formas de infecção.

O filme "Cazuza o tempo não para" em uma das suas cenas relata esta realidade, quando o cantor descobre que estar infectado com o vírus fica evidente quando ele diz: "o médico disse que eu fui tocado pela aids, não posso emprestar roupa para ninguém, que eu não posso beijar e tudo que é meu deve ser separado" (CAZUZA o tempo..., 2004). O pai do cantor João Araújo, em um depoimento ao livro só as mães são felizes, confirma esta ideia que a sociedade e os médicos possuíam na época "só para se ter uma ideia, as primeiras recomendações foram no sentido de não se comer no mesmo prato que o doente, não usar as mesmas roupas, não beijar. Todos os seus objetos de uso pessoal deveriam ser esterilizados" (ARAÚJO, 2000, p.80).

Hoje, a sociedade evoluiu a respeito da convivência com seus portadores. O governo passou a investir nas campanhas preventivas e informações sobre as formas de contágios, no entanto o preconceito ainda está ativo na mente do corpo social não tanto, quanto as barreiras da década de 80, mas ainda prevalece. "Várias empresas hoje possuem nos seus quadros, funcionários soropositivos e/ou que vivem com aids. $\mathrm{O}$ preconceito e discriminação diminuíram muito, mas ainda existe" (SANTANA, 2012, online). Pois os estereótipos criados sobre os portadores é o que ocasiona a resistência para o entendimento e continuidade com o preconceito.

\begin{abstract}
A imagem de um portador da AIDS que nos salta dos arquivos da memória é sempre a de uma pessoa magra, debilitada, com o corpo coberto de manchas, deitada sobre uma cama definhando, sofrendo solitária e abandonada. Esta imagem foi verdadeira um dia, é bem verdade, mas já faz muito tempo. Hoje com o advento de novas e potentes drogas e os avanços terapêuticos, na maioria das vezes é muito difícil, reconhecer um portador do HIV, principalmente quando em estado assintomático, simplesmente olhando para ele. No cotidiano o que diferencia uma pessoa soropositiva das outras é o preconceito (FERREIRA, 2001, p. 21).
\end{abstract}

Os grandes desenvolvimentos para o controle da pandemia são visíveis, os avanços nos medicamentos antirretrovirais, portadores do vírus vivendo mais em comparação aos que foram os primeiros casos. Todavia, a preocupação também deveria ser repensada na forma que as informações a respeito do vírus estão sendo repassada e refletida para que a população não sinta impactos equivocados dos portadores. Através das organizações de informações verídicas para que estas sejam disseminadas de forma correta, sem bases de interesses pessoais como ocorre através do sensacionalismo. 


\section{MEDIADOR UMA POSSIVEL RELAÇÃO: NAS CAUSAS DE UM SINTOMA SOCIAL, O BIBLIOTECÁRIO ATUA}

O bibliotecário, profissional que trabalha com a organização, pesquisa e disseminação da informação no âmbito interdisciplinar. Tem real importância social em mediar às informações para que os seus usuários venham ter o conhecimento ao seu alcance de forma coerente e satisfatória. Para isto no que diz respeito a contribuir na disseminação da informação sobre o vírus HIV/AIDS, no qual ainda é abordado, sobre as formas de preconceito e medo devido às faltas de informações sobre o vírus.

Gostaríamos que você nos corrigisse caso estejamos errados - que o principal trabalho do nosso querido profissional bibliotecário é, exatamente, a informação. Correto? Ora, por que é então, que o bibliotecário (o tal profissional da informação vale enfatizar) nada faz para informar a população sobre a AIDS, contribuindo para diminuir o número de contágios? (ALMEIDA JUNIOR, 1997, p.87).

Disseminar a informação não está ligado apenas às técnicas e o ambiente de acervos para que cheguem aos usuários. Muitas das vezes o bibliotecário se limita nas suas unidades de informação com o pensamento que está contribuindo na propagação da informação, mas nesses ambientes existe o público no qual vem em busca de suas próprias ciências e que não estão excluídos das informações.

Inúmeras campanhas sobre as doenças sexualmente transmissíveis estão à disposição da população. Porém, é preciso ressalvar que ainda existem cidadãos desprovidos de informações verídicas sobre o assunto das doenças sexualmente transmissíveis, especificamente sobre o vírus HIV. Populações que não possuem a cultura, condições ou o alfabetismo de frequentar uma biblioteca, buscar informações ou de levar a sério as campanhas nacionais. No qual obtêm informações apenas através do rádio, televisão ou jornal, sendo que estes meios, muitas vezes, transmitem informações superficiais ou não tão confiáveis.

A vida atual exige que os indivíduos sejam informados o tempo todo: necessitam conhecer notícias, fatos, instruções, padrões, regras de procedimentos, normas, estatísticas, etc. Mas, é necessário não esquecer que o mais importante não é a quantidade de informação disponível, e sim a sua qualidade (CUNHA, 2003 p.4).

Decorrido da falta ou do excesso de informações que a sociedade obtém, o profissional bibliotecário tem fundamental importância em levar seu profissionalismo no papel social como mediador fazendo a inserção para aqueles que ainda estão carentes de informação. Na qual Castro e Ribeiro afirmam (1997, p.21) "ao lado da sociedade da informação, há sem dúvida, outra - a sociedade da desinformação (...) ". Como uma de suas responsabilidades profissionais, o bibliotecário possui a importância de prestar informação a diferentes usuários sem deixar nenhum desprovido do saber. Porém é preciso prestar assistencialismo a camada social menos favorecida de informações no qual, muitas das vezes é esquecida, ou achar que não precisa levar tão a sério a questão do vírus, HIV/AIDS. 
Nós precisamos atingir a população carente, a população carente de informações. Não será com essa postura apática, passiva e reacionária da biblioteca de hoje que o conseguiremos. Não basta espalharmos bibliotecas em cada quarteirão, em cada esquina. É preciso que ele seja consciente da sua real função social; é preciso que ele saiba que seu trabalho pode e deve alterar pensamentos e comportamentos; é preciso que ele vá até a população, que ele trabalhe com a comunidade (ALMEIDA JUNIOR, 1997, p. 92).

Levar a informação aos que necessitam, torna-se fator importantíssimo para acrescentá-la tanto ao seu conhecimento social quanto ao profissional. Visto que, "é necessário não esquecer que o trabalho de informação é um trabalho de troca - é através desta troca que crescemos e obtemos mais informações" (CUNHA, 2003, p.42).

O bibliotecário que acomoda seu trabalho em técnicas de catalogação, classificação e a indexação, isola-se em paredes, não contribuindo com seu real papel, pois a biblioteca tem um papel cultural devastador, seu sinônimo é emancipação do conhecimento, não retraindo as técnicas, mas propor uma diversificação de forma mais prática, para ser mediada a informação. Não sendo mais como o profissional cômodo, sendo visível perceber a sua contribuição em sociedade.

A população não nos conhece como úteis socialmente. E sabem por quê? Porque insistimos em não reconhecer a nossa verdadeira função social que não é apenas incentivar a leitura, mas trabalhar com a informação, levá-la àqueles que dela necessitam (ALMEIDA JUNIOR, 1997, p. 92).

O bibliotecário tem muito a contribuir na sociedade, pois ele possui uma das ferramentas imprescindíveis para agregar valor na educação social com o conhecimento em fontes de informações impressas e eletrônicas, bases de dados especializadas, no que se refere à informação atuando junto a outros profissionais, tendo às competências em fazer o uso da mediação nos diferentes setores, ambientes e aspectos sociais. Conforme aborda Liston e Santos $(2008$, p.2) "o bibliotecário é capaz de trabalhar a informação de modo a atender as necessidades da sociedade em seus aspectos políticos, econômicos, educacionais, sociais, de saúde, culturais, recreativas e tecnológicas (...)". Miranda (2004, p.118) enfatiza que "o acesso à informação ou a facilitação desse acesso é o objetivo desses profissionais, que atendem a usuários (...) divididos em grupos com características e demandas de informação diferenciadas".

Com a prática destas atitudes, este profissional conquistará tanto a sua função em utilidade pública, quanto sua prática de disseminador multidisciplinar na sociedade. Uma vez que a camada social passará a levar mais a sério as orientações quando as mesmas forem mais assistenciais.

O governo vem investindo nas divulgações no que diz respeito às prevenções, testes rápidos e medicamentos novos sobre o vírus, a Organização Mundial da Saúde (OMS) 
divulga dados sobre os respectivos portadores, cientistas buscam vacinas cada vez mais eficazes. Valendo-se dessas informações o bibliotecário tem muito a contribuir na organização destas informações, na forma de levar as atualizações sobre o assunto, ou seja, no apoio onde as informações governamentais não consigam ser alcançáveis.

Disseminando assim seu papel social em parceria com as ONGs, com os profissionais da área médica, ou seja, na prestação de seus serviços em contribuição com as diferentes áreas. Pois, "a biblioteconomia é reconhecida como uma área interdisciplinar sendo assim precisa da contribuição de outras áreas" (ALMEIDA JUNIOR, 1997, p.94). Dessa forma a busca de disseminar e alcançar a sociedade, será papel do bibliotecário. Deste modo, ser criativo e dinâmico procurando sempre maneiras de se inserir mais em sociedade e buscando de contínuo refletir criticamente sobre o estado social em que vive (LISTON; SANTOS, 2008).

Tendo em vista que sua função é contribuir para o desempenho do papel social, frente às informações do HIV/AIDS, em bases de dados na área medicina, no qual o profissional bibliotecário tem conhecimento, como a Medline, BVS, Web of Science, das quais apresentam informações e a atualizações sobre o assunto. Em exemplo a Medline, na qual possui a introdução do termo AIDS desde 1983, disponibilizando diferentes filtros de buscas desde sexo, idade até textos completos gratuitos.

Com o alcance de informações não tem o porquê de não promover o exercício da informação nas comunidades sociais. Para trabalhar nos fatores em que a população realmente tenha suas dúvidas a respeito do vírus, as suas reais formas de transmissões em questões muitas das vezes incógnitas na mente das pessoas. E ajudando o País a alavancar ainda mais nas respostas da informação certa e assistência no combate a AIDS, uma vez que para a ONU (2013) o Brasil vem obtendo bons índices sobre o combate a AIDS chegando a tornar-se líder.

\section{CONSIDERAÇÕES FINAIS}

Esta pesquisa mostrou a capacidade do profissional bibliotecário de disseminar a informação sobre um assunto, muitas das vezes, visto como polêmico pela sociedade, no que se refere ao Vírus HIV/AIDS. Visto que, diante dos estudos que abordam o papel social do bibliotecário, a pesquisa obteve características imprescindíveis no qual, este profissional é capaz de desenvolver frente as causas sociais. No que dizem em respeito, a pesquisar em fontes de informação impressa eletrônica, organização e disseminação da informação sobre o público-alvo e sua interdisciplinaridade nos estudos em relação a diversas áreas.

Para o desenvolvimento da pesquisa foi utilizado duas bases de dados MEDLINE, onde a pesquisa procurou artigos publicados na década de 80, como foi descrita o HIV na área da medicina naquela época; e a BVS (Biblioteca Virtual em saúde) onde foram encontrados artigos que se refere a inibir HIV vírus drogas, incluindo zidovudina (AZT) em que se encontra divulgada pelo Ministério da saúde do Brasil. 
A abordagem na sociedade sobre HIV e a AIDS, ainda é um tema que precisa ser debatido com mais aprofundamento, pois muitos cidadãos ainda acreditam em falácias sobre o assunto, o que consequentemente ocasiona o preconceito ainda existente na sociedade. Portanto, não podemos negligenciar a existência de pessoas que ainda não possuem acesso a informações a respeito do vírus, no que diz respeito, suas reais transmissões, maneiras de prevenção, e as atualidades que envolvem as pesquisas sobre o vírus HIV.

A partir da falta de informação que ainda é vivenciada, a contribuição do bibliotecário de exercer seu trabalho juntamente aos grupos sociais, será de grande relevância, pois muitas das vezes, os grupos que prestam assistência social ainda são carentes de profissionais capacitados que buscam auxiliar seu projeto.

Pois, o bibliotecário como o defensor da investigação científica e da dignidade do ser humano, deve contribuir através de suas competências em disseminar a informação, para os que não possuem acesso ao assunto, ou os que possuem, mas não de forma esclarecedora.

A pesquisa entendeu que uma das causas para o pouco reconhecimento e valorização do bibliotecário na sociedade, ocorre pelo fato deste profissional não está muito inserido em causas sociais, ou seja, partindo em busca de usuários para que estes recebam suas informações, e consequentemente entendendo a importância deste profissional em suas vidas. Como disseminador da informação o bibliotecário precisa demonstrar sua importância e comprometimento social além de quatro paredes e unidades de informações. Porquanto os profissionais da informação, neste ponto ressalto o bibliotecário, é imprescindível neste contexto, onde contribui com os profissionais da saúde, para tirar as incertezas, auxiliando nas informações convalidadas para os próprios portadores do vírus e a sociedade.

Conclui-se que o bibliotecário precisa desenvolver seu papel social de acordo com suas especialidades e estudos nos quais se identifica. Não apenas no que se refere ao assunto tratado nesta pesquisa. Pois cada profissional tem aptidão para um determinado assunto. Porém, é necessário que independente de suas preferências não seja esquecido a sua importância na contribuição social, pois sempre existirá muito a fazer quando envolve informação na sociedade.

\section{REFERÊNCIAS}

ALMEIDA JÚNIOR, Oswaldo Francisco de. Sociedade e Biblioteconomia. São Paulo: Polis, 1997.

ARAÚJO, Lucinha. Cazuza: só as mães são felizes. São Paulo: Globo, 2000.

BARRETO, Aldo de Albuquerque. A estrutura do texto e a transferência da informação.

Data grama zero - Revista de Ciência da Informação, v.6, n.3, jun. 2005. Disponível em: <http://eprints.rclis.org/17638/1/DataGramaZero\%20\%20Revista\%20de\%20Ci\%C3\%AAnci 
a\%20da\%20Informa\%C3\%A7\%C3\%A3o\%20-\%20Artigo\%2001-2005.pdf>. Acesso em: 20 jan. 2014.

BRASIL. Ministério do trabalho. Portaria n $\mathrm{n}^{\circ}$ 1.927, de 10 de dezembro de 2014. Estabelece orientações sobre o combate à discriminação relacionada ao HIV e a AIDS nos locais de trabalho, cria a Comissão Participativa de Prevenção do HIV e AIDS no Mundo do Trabalho e dá outras providências. Brasília: Diário Oficial da União (DOU), 2014. Disponível em: < http://zeroacidentes.com.br/wp-content/uploads/2014/12/PORTARIA-MTE-N\%C2\%BA1.927-DE-10-DE-DEZEMBRO-DE-2014.pdf>. Acesso em:15 abr. 2015.

BRASIL. Ministério da saúde. Secretaria de Vigilância em Saúde. Programa Nacional de DST e AIDS. O remédio via justiça: um estudo sobre o acesso a novos medicamentos e exames em HIV/AIDS no Brasil por meio de ações judiciais. Brasília: Ministério da Saúde, 2005.

BRASIL. Ministério da Saúde. Aids no Brasil: um esforço conjunto governo-sociedade. Brasília: Coordenação Nacional de DST e aids, MS, 1998.

CAMPELLO, Bernadete. O movimento da competência informacional: uma perspectiva para o letramento informacional. Ciência da informação, Brasília, v. 32, n. 3, set./dez. 2003. Disponível em: 〈http://www.scielo.br/pdf/ci/v32n3/19021.pdf>. Acesso em: 20 jan. 2014.

CASTRO, César Augusto; RIBEIRO, Maria Solange Pereira. Sociedade da informação: dilema para o bibliotecário. Transinformação, v. 9, n. 1, 1997. Disponível $\mathrm{em}:\langle$ http://periodicos.puc-campinas.edu.br/seer/index.php/transinfo/article/view/1589>. Acesso em 28 abr. 2014.

CAZUZA o tempo não para. Direção: Sandra Werneck e Walter Carvalho. Produzido: Daniel Filho. Intérpretes: Marieta Severo; Reginaldo Faria; Daniel de Oliveira; Emílio de Mello; Andréa Beltrão. [s.1]: Globo Filmes, 2004. 1 DVD (98 min), color.

CUNHA, Miriam Vieira da. O papel social do bibliotecário. Encontro Biblio Revista eletrônica de biblioteconomia e ciência da informação, Florianópolis, n.15, 2003. Disponível em: <https://periodicos.ufsc.br/index.php/eb/article/viewFile/15182924.2003v8n15p41/5234 >. Acesso em: 20 jan. 2014.

DEPARTAMENTO de DST, Aids e Hepatites Virais. O que é HIV. Disponível em: <http://www.aids.gov.br/pagina/o-que-e-hiv>. Acesso em: 17 maio 2015.

DOURADO, Inês et al. Tendências da epidemia de Aids no Brasil após a terapia antiretroviral. Rev. Saúde Pública, v.40, supl. 9-17, 2006. Disponível em: $<$ http://www.scielo.br/pdf/rsp/v40s0/03 > . Acesso em: 26 maio 2014. 
FERREIRA, Camila da Silva. AIDS: O preconceito no contexto familiar. Rio de Janeiro. 2001. 52 f. Monografia (Especialização em Terapia da família) - Universidade Cândido Mendes, Rio de Janeiro, 2001. Disponível em: http://www.avm.edu.br/monopdf/3/CAMILA\%20DA\%20SILVA\%20FERREIRA.pdf. Acesso em: 15 abr. 2015.

GIL, Antonio Carlos. Como elaborar projetos de pesquisa. 4. ed. São Paulo: Atlas, 2008.

GRANGEIRO, Alexandre; SILVA, Lindinalva Laurindo da; TEIXEIRA, Paulo Roberto. Resposta à aids no Brasil: contribuições dos movimentos sociais e da reforma sanitária. Rev Panam Salud Publica, v. 26, n. 1, 2009. Disponível em: <http://www.scielosp.org/pdf/rpsp/v26n1/13.pdf > . Acesso em: 23 maio 2014.

LISTON, Rose Cristiani Franco Seco; SANTOS, Plácida da Costa. Representando a Information Literacy "Competências Informacionais" na Biblioteconomia. Revista em questão, v. 14, n. 2, jul./dez. 2008. Disponível em:

<http://seer.ufrgs.br/EmQuestao/article/view/5043>. Acesso em: 22 maio 2014.

MARQUES, Maria Cristina da Costa. Saúde e poder: a emergência política da Aids/HIV no Brasil. Revista História, ciência, saúde - Manguinhos , Rio de Janeiro, v. 2, supl. 2002. Disponível em: $<$ http://www.scielo.br/scielo.php?script=sci_arttext\&pid=S010459702002000400003\&lng=p t\&nrm=iso $>$. Acesso em 03 jan. 2014.

MENEGHIN, P. Entre o medo da contaminação pelo HIV e as representações simbólicas da AIDS: o espectro do desespero contemporâneo. Rev.Esc.Enf.USP, v.30, n.3, p. 399-415, dez. 1996.

MIRANDA, Silvânia Vieira. Identificando Competências Informacionais. Ciência da Informação, Brasília,DF, v. 33, n. 2, p. 112-122, maio/ago., 2004. Disponível em: <http://revista.ibict.br/ciinf/index.php/ciinf/article/view/83>. Acesso em: 26 fev. 2014.

PEREIRA, Adriana Jimenez; NICHIATA, Lúcia Yasuko Izumi. A sociedade civil contra a Aids: demandas coletivas e políticas públicas. Ciênc. saúde coletiva, Rio de Janeiro, v. 16, n.7, jul. 2011. Disponível em: 〈http://www.scielo.br/pdf/csc/v16n7/24.pdf >. Acesso em 23 maio 2014.

PIOVESAN, A. Da necessidade das escolas de saúde pública elaborarem métodos simplificados de investigação social. S. Paulo, 1968. [Tese de Doutorado - Faculdade de Saúde Pública da USP].

SADALA, Maria Lúcia Araújo; MARQUES, Sílvio de Alencar. Vinte anos de assistência a pessoas vivendo com HIV/AIDS no Brasil: a perspectiva de profissionais da saúde. Cad. 
Saúde Pública, v.22, n.11, p. 2369-2378, nov. 2006. Disponível em: < http://www.scielo.br/pdf/csp/v22n11/11.pdf> . Acesso em: 23 maio 2014.

SANTANA, Almir. AIDS no trabalho: Discriminação ainda existe. Infonet, maio 2014. Disponível em:

<http://www.infonet.com.br/almirsantana/ler.asp?id=127582\&titulo=almirsantana $>$. Acesso em 20 jan. 2014.

SILVA, Silvia Fernandes Ribeiro, et al. Aids no Brasil: uma epidemia em transformação. Revista Brasileira de análises clínicas, Rio de Janeiro, v. 42, n. 3, 2010. Disponível em: <http://www.sbac.org.br/pt/pdfs/rbac/rbac_42_03/rbac_42_v3_012.pdf $>$. Acesso em: 03 jan. 2014

SOUSA, A.M. et al. A política de AIDS no Brasil: uma revisão de literatura. J. Manag. Prim. Health Care, 2012; 3(1):62-66. Disponível em:

<http://www.jmphc.com/ojs/index.php/01/article/view/38/34>. Acesso em: 19 jan. 2015.

Como citar este documento:

OLIVEIRA, Alessandra Nunes de; CASTRO, Jetur Lima de. Nas causas de um sintoma social o bibliotecário atua: a mediação e uso da informação como fonte de interposição sobre o vírus HIV. Revista Digital de Biblioteconomia e Ciência da Informação, Campinas, SP, v. 13, n. 2, p. 229-242, maio/ago. 2015. ISSN 1678-765X. Disponível em: $<$ http://periodicos.bc.unicamp.br/ojs/index.php/rdbci/article/view/8635038>. Acesso em: 31 Mai. 2015. 